\title{
O 'assumir' na emergência do movimento homossexual brasileiro: os casos do Somos (SP), Grupo Gay da Bahia (BA) e Dialogay (SE)
}

\section{The emergence of coming out the Braziliam homossexual movement: the cases of Somos (SP), Grupo Gay da Bahia (BA) and Dialogay (SE)}

Paulo Roberto Souto Maior Júnior*

\begin{abstract}
Resumo
$O$ artigo analisa os significados do se assumir homossexual na emergência do movimento homossexual brasileiro da passagem das décadas de 1970-80, especificamente no caso do grupo Somos (São Paulo), do Grupo Gay da Bahia (Salvador) e do Dialogay (Aracaju). Para tanto, são apresentadas as condições de emergência dessa militância, as propostas de cada organização e quais maneiras foram elaboradas para construir uma determinada modalidade de assumir publicamente uma identidade homossexual. Metodologicamente, recorro a uma análise discursiva de inspiração foucaultiana.
\end{abstract}

Palavras-chave: Assumir-se; Movimento homossexual; Grupo Somos; Grupo Gay da Baia; Dialogay.

\begin{abstract}
This article analyses the meanings of assuming someone's homosexuality in the emergency of the Brazilian homosexual movement of the decades of 1970-80, in the specific case of the groups: Somos (São Paulo), Grupo Gay da Bahia (Salvador) and Diaogay (Aracaju). For that, the emergency conditions of this militancy, the propositions of each organization and the ways that have been elaborated in order to built a way of taking over publicly a homosexual identity are presented. Methodologically, I betake to a discursive analysis of foucaultian inspiration.
\end{abstract}

Keywords: Coming out; homosexual movement; Somos; Grupo Gay da Bahia; Dialogay.

*Doutorando em História pela UFSC. E-mail: paulosoutom@gmail.com 
A linguagem é um mapa e não um decalque ${ }^{1}$

O objetivo deste artigo é analisar o espaço ocupado pela visibilidade das homossexualidades na fundação do movimento homossexual brasileiro (1978-1981), sobretudo nos seguintes grupos de ativistas: "Somos", de São Paulo; "Grupo Gay da Bahia”, de Salvador; e "Dialogay", de Aracaju.

Optei por partir da organização paulista por ser considerada a pioneira; ela teria influenciado várias outras em diferentes regiões do Brasil. É o que se percebe na documentação epistolar do "Somos", recebendo cartas de grupos de todo o país. Dentre eles, havia o Grupo Gay da Bahia que influenciou decisivamente o Dialogay, de Aracaju. Recorto, também, os dois grupos nordestinos para dar importância a geografias da história das homossexualidades muitas vezes esquecidas por não terem como epicentro a região sudeste, notadamente Rio de Janeiro e São Paulo, sobre a qual prevalecem uma série de pesquisas ${ }^{2}$.

Especifico, ainda, que o objetivo não é narrar uma história dessas organizações, mas, reunindo algumas fontes como notícias em revista, depoimentos orais, boletins informativos, analisar de que maneira se tocava na questão do assumir-se homossexual, estudando os seus significados.

Compreendo o assumir como um conceito que, portanto, guarda armadilhas, segredos, promessas. Estudar conceitos significa desmistificar muito mais do que a sua morfologia e sintaxe permitem compreender. 0 mundo dos conceitos não cabe na gramática porque a linguagem é política, as mensagens entre emissor-receptor podem acionar camadas de sentido que deem significados à vida, criando lugares instigantes à espera dos sujeitos.

O conceito de assumir tem conexão direta com o movimento homossexual da primeira onda. ${ }^{3}$ Para que ocorra movimento, é preciso fabricar um conjunto de referências. Uma das mais necessárias ao movimento homossexual foi fazer os homossexuais assumirem o seu desejo. Grupos, refletiu Michel de Certeau, recorrem a uma "vontade construtiva", frequentemente investem em formas de reconhecimento para atrair adeptos, garantindo,

\footnotetext{
${ }^{1}$ DELEUZE, Gilles e GUATTARI, Félix. 1995-1997. Mil Platôs, volume 2. Rio de Janeiro: Editora 34, p. 14. ${ }^{2}$ SIMÕES, Assis Júlio e FACCHINI, Regina. Na trilha do arco- íris: movimento homossexual ao LGBT. Ed. Fundação Perseu Abramo, 2009. GREEN, James. Além do carnaval: a homossexualidade masculina no Brasil do século XX. São Paulo: Editora Unesp, 2000

${ }^{3}$ A expressão "primeira onda" foi apropriadamente cunhada por Regina Facchini. Ver: FACCHINI, Regina. "Movimento homossexual no Brasil: recompondo um histórico". Cadernos Arquivo Edgard Leuenroth (UNICAMP), Campinas, v. 10, n.18/19, p. 79-123, 2003.
} 
assim, a organização de iniciativas e levando os seus adeptos a perceberem que não estão sozinhos, que não sejam os únicos na organização. ${ }^{4}$

Uma breve observação. Edward MacRae já escrevia, em 1987, que o movimento homossexual operaria numa contradição: ao mesmo tempo em que desejava barrar a regulação da sexualidade, abarcava e se afirmava por meio de categorias. $\mathrm{O}$ antropólogo observou: "No Somos/SP, como em todos os outros grupos homossexuais sobre os quais tenho dados, não se permite a participação de indivíduos que se identifiquem como 'heterossexuais' e até bissexuais são encarados com certa reserva e suspeita". ${ }^{5}$ Isto é, um movimento que visava à inclusão nascia excluindo e demarcando territórios destinados apenas aos homossexuais.

Mais adiante, esclarece que o principal objetivo do grupo foi uma afirmação homossexual tanto pública quanto privada. Penso que o texto de MacRae poderia ter levado a fundo como se deu esse processo de se assumir no âmbito da militância. Tal argumento não é simples e tampouco se pode presumir que há algo dentro do indivíduo e, quando interpelado, ele afirmaria. Há, isto sim, um aprendizado do que seria a homossexualidade e de que era preciso expô-la.

Esse movimento ocorreu paralelamente a discursos sobre as homossexualidades, se distanciando dos saberes médicos e psicanalíticos. As matérias a respeito do tema, veiculadas em parte da grande mídia, contribuíram muito para que, aos poucos, se dissipasse o caráter patológico que lhes atravessava. Como efeito disso tudo, não havia mais como negar que as homossexualidades estavam em cena e os diversos discursos que homossexuais formularam para tentar compreendê-la e legitimá-la foram acompanhados de uma presença frequente de espaços de sociabilidades destinado ao público, notadamente nas capitais. Felizes com o que se passava e ciosos de aproveitar o momento para reivindicar direitos um grupo de pessoas, foi criado o movimento homossexual brasileiro.

A história do grupo "Somos" já foi suficientemente contada por Edward MacRae ${ }^{6}$ e pelo escritor João Silvério Trevisan. ${ }^{7}$ Apoiando-me neles, destaco

\footnotetext{
${ }^{4}$ CERTEAU, Michel de. “As revoluções do “crível””. In: A cultura no plural. Campinas: Papirus, 2012, p. 39. ${ }^{5}$ MacRAE, Edward. Afirmação da identidade homossexual: seus perigos e sua importância. In.: FOUCAULT, Michel. In.: TRONCA, Ítalo A. (Org.). Foucault vivo. Campinas, SP: Pontes, 1987, p.83.

${ }^{6}$ MacRAE, Edward. A construção da igualdade: Identidade sexual e Política no Brasil da “abertura”. Campinas: UNICAMP, 1990. p. 108.

${ }^{7}$ TREVISAN, João Silvério. Devassos no Paraíso: A homossexualidade no Brasil, da colônia à atualidade. Rio de Janeiro: Record, 2007.
} 
algumas características da organização. Um dos mitos de origem está relacionado à Semana da Convergência Socialista, planejada pela revista Versus em 24 e 30 de abril de 1978. Dentre as pautas de discussões, estavam: anistia; liberdades sindicais; imprensa alternativa. Os organizadores boicotaram a presença da imprensa homossexual na figura do recém-criado Lampião da Esquina. Porém, os membros do periódico foram informados da tentativa de exclusão e elaboraram uma moção de protesto lida no momento do debate sobre a imprensa.

Enfrentando o preconceito e machismo de membros de outros grupos ali presentes, os homossexuais reivindicaram pautas e demandas específicas. De acordo com MacRae, esse episódio foi importante porque inaugurou uma discussão pública em defesa das homossexualidades.

Desse acontecimento se firmou um grupo para prosseguir com discussões sobre o tema. Era formado, no início, predominantemente por homens, alguns dos quais só participaram das primeiras reuniões, temendo serem reconhecidos como homossexuais. Paulatinamente, o número de pessoas cresceu de forma suficiente, atingindo a cifra de 100 integrantes.

No Núcleo de Ação pelos Direitos dos Homossexuais, batizado em dezembro de 1978 e passando a se chamar "Somos", as primeiras reuniões funcionavam como a descoberta de uma "essência homossexual". ${ }^{8}$ Para isso, os grupos de identificação, ${ }^{9}$ caracterizados por uma conscientização das homossexualidades, tiveram considerável importância. Já ali, porém, tensões tomaram conta do grupo devido a uma ala que defendia com urgência um enfoque predominantemente político das homossexualidades.

A luta por reconhecimento social ganhou força com a formação e atuação dos grupos homossexuais, entre os quais o "Grupo Gay da Bahia" (GGB), fundado em 1980 pelo professor Luiz Mott. Certamente, é o mais antigo grupo de homossexuais do Brasil, funcionando sem cessar desde a sua fundação. Logo no começo, procurando firmar-se nesse campo de luta, o GGB tornou-se membro da International Lesbian Gay Association ${ }^{10}$ (ILGA), uma organização internacional que congrega os principais grupos de ativismo empenhados na promoção da cidadania e demais interesses de gays, lésbicas e trans.

\footnotetext{
${ }^{8}$ MacRAE, op. cit., p. 101.

${ }^{9}$ Ibidem, p. 101.

${ }^{10}$ Fundada em 1978, a ILGA é uma federação que procura atuar em nível global visando à promoção de direitos e cidadanias de lésbicas, gays, bissexuais, travestis, transexuais e outras sexualidades. Maiores informações podem ser consultadas no site da associação: http://www.ilglaw.org/. Acesso em: 26 jun. 2016.
} 
A história do grupo vem sendo contada do ponto de vista do seu fundador, Luiz Mott, que, em meados da década de 1970, era antropólogo e professor da Universidade Estadual de Campinas (UNICAMP), mas tinha um desejo de morar no nordeste. O sonho se realizou e o lugar escolhido foi Salvador.

Certa vez, acompanhado de Aroldo, seu ex-namorado, conta: "estávamos juntos no Porto da Barra... atrás do Farol da Barra vendo o pôr do sol, sentados discretamente, quando um rapaz nos viu sair de lá. Na hora que fui pegar minha moto, ele me deu um bofetão na cara."11 Essa narrativa foi ressaltada em entrevista que concedeu ao historiador Claudio Silva, em 1994. A eleição desses eventos constitui pontos centrais na subjetividade militante de Luiz Mott, costumeiramente reportando-se a ele como fez em recente entrevista ao jornal A tarde, da Bahia. ${ }^{12}$ É ainda revelador como nas suas seleções de memória para a entrevista a agressão é simultânea à assinatura do Lampião da Esquina, das notícias de fundação do grupo "Somos" em São Paulo, Sorocaba e Rio de Janeiro. Pelo que se sabe, Mott não participou ativamente dos grupos ou do jornal, mas trocava correspondências com ambos.

Esses eventos incentivaram-no a criar um grupo em Salvador. Conheceu alguns anarquistas, jornalistas e professores. A primeira reunião se deu numa noite de sábado, 29 de fevereiro de 1980, e contou com dezessete pessoas: Ricardo Lipper, Antônio Carlos Pacheco, Alexandre Ferraz (os três integraram o jornal anarquista "O inimigo do Rei", em Salvador); Carlinhos; Aroldo; Wilson Santana; Édimo Santana; Huides Cunha; Davi Aranha, dentre outros. Uma das metas foi criar um boletim informativo que contou com a colaboração de Edward MacRae e João Antônio Mascarenhas.

A partir de agosto de 1981 o "GGB" colocou em circulação o seu primeiro boletim, pouco mais de um ano após a sua fundação. O objetivo era alcançar sobretudo outras organizações homossexuais. A triagem inicial correspondia a 250 - 400 exemplares. Entre 1981 e 2005, 47 edições foram produzidas. Da sua produção, cerca de 250 exemplares eram distribuídos na Bahia; o restante era enviado para outros grupos. ${ }^{13}$

No prefácio à compilação do boletim, a historiadora Rita Colaço destacou que o "GGB" "dá seguimento ao projeto de ser um grupo efetivamente de atuação e conscientização. Por meio de seu Boletim, passa a ocupar,

\footnotetext{
${ }^{11}$ SILVA, Claudio Roberto. Reinventando o sonho: história oral de vida política e homossexualidade no Brasil Contemporâneo. Dissertação (Mestrado em História) - Universidade de São Paulo, São Paulo, 1998, p. 459. ${ }^{12}$ Jornal A tarde. 16 nov. 2008. Disponível em: http://www.ggb.org.br/mott_entrevista.html. Acesso em: 10 mar. 2016.
}

${ }^{13}$ Boletim Grupo Gay da Bahia. Salvador: Editora GGB, 2011. p. 22. 
notadamente no Norte e Nordeste, o vazio deixado com o encerramento do Lampião da Esquina". ${ }^{14}$

O boletim teve como principal objetivo divulgar as atividades realizadas pelo grupo. Some-se a isso: notícias de atividades desenvolvidas por outras organizações; lista de homossexuais assassinados por homofobia; dicas de lugares de sociabilidades; recomendações de livros, a exemplo de 0 comportamento sexual do brasileiro, de Délcio Monteiro de Lima ${ }^{15}$; concursos de poesias entre leitores. Com relação ao uso de palavras como bicha e sapata, o grupo inspirou-se no Lampião, usando-as para positivá-las, atribuindo-lhes novos sentidos, desvinculando-as do ar preconceituoso.

Em 1980, numa viagem pelo nordeste, passando por Maranhão, Natal, Teresina, Fortaleza, Recife, Luiz Mott percebeu um baixo nível de conscientização homossexual por parte dos homossexuais. Em carta que enviou ao Somos em 5 de agosto de 1980, conta que tentou divulgar informações sobre o movimento homossexual e as experiências vividas em Salvador e São Paulo. Mas a tentativa de "fazer um pouco de apostolado gay", nas palavras do antropólogo, encontrou desafios. Escreveu: "Em toda parte, só badalações pelas ruas, as bichas, coitadinhas, alienadérrimas, naquela ainda de bichaxbofe etc." ${ }^{16}$ É possível que nessas andanças tenham fincado algumas raízes; pelo menos em Sergipe ela foi promissora.

O Lampião da Esquina começou a ser comercializado em Aracaju em 1980, sendo que o lançamento se deu no Diretório Central dos Estudantes da Universidade Federal de Sergipe, sob iniciativa de Wellington Andrade, que conhecera o jornal no final dos anos $1970 .{ }^{17}$

Luiz Mott escreveu uma carta ao "Somos" solicitando endereços de outros grupos homossexuais no norte e nordeste: "Nós do GGB vamos em comitiva à Sergipe, logo após o carnaval, a fim de contactuar (sic) as bichas sergipanas". ${ }^{18}$ Talvez aí tenha conseguido o endereço de Wellington e incentivou-o a criar uma organização gay em Sergipe. Com êxito, em 14 de março de

\footnotetext{
${ }^{14}$ RODRIGUES, Rita de Cássia Colaço. “Prefácio”. Boletim Grupo Gay da Bahia. Salvador: GGB, 2011.

${ }^{15}$ LIMA, Delcio Monteiro. Comportamento sexual do brasileiro. Rio de Janeiro: Francisco Alves, 1977.

${ }^{16}$ MOTT, Luiz. Carta enviada ao Somos, 05 de agosto de 1980. Fundo documental do grupo Somos do AEL/ UNICAMP.

${ }^{17}$ MELO, Marcus Ribeiro de. Condições Histórico-Sociais do movimento "homossexual/LGBT" em Aracaju (1981-1996). IV Fórum de Identidades e Alteridades: Educação e Relações Étnico-raciais. Itabaiana/SE. 2010. Disponível em: http://200.17.141.110/forumidentidades/IVforum/textos/Marcos_Ribeiro_de_Melo. pdf. Acesso em: 15 jun. 2016.
}

${ }^{18}$ MOTT, op. cit., 23 de fevereiro de 1981. 
1981, na casa de Wellington Andrade, era fundado o "Dialogay", em Aracaju. Os participantes totalizavam sete, sendo quatro homens e três mulheres.

Importante destacar o incentivo dado por Luiz Mott à organização. Não poupou esforços em palestras, doação de livros, cartazes, panfletos, fornecimento de dicas de militância e divulgação do grupo no boletim do "GGB". ${ }^{19}$

Havia, evidentemente, algumas sociabilidades homossexuais em Aracaju anteriores ao "Dialogay". I.C.L. ${ }^{20}$ um dos membros fundadores, colaborou na fundação do Partido dos Trabalhadores (PT), em 1980, em Sergipe e, portanto, possuía experiências em organizações e mobilizações sociais. Anos antes, na década de 1970, entretanto, I.C.L. vivenciou problemas com o seu desejo no âmbito religioso. Sua orientação sexual causou-lhe problemas com o credo protestante do qual fazia parte. Por resultado, ingressou numa igreja católica e fundou, com a ajuda de um padre, uma "Comunidade Católica Homossexual". Nas reuniões, ocorridas no interior da casa do padre, ensinava-se que a homossexualidade não era pecado. ${ }^{21} \mathrm{O}$ principal objetivo do grupo era investir numa militância homossexual, engajamento que exigiu a elaboração de um orgulho de ser gay, indo na contramão da maneira como o desejo era visto na sociedade de modo geral: uma vergonha. Estes grupos interviram no espaço público, tentando dar voz aos homossexuais; um voz comum, militante e que teria no se assumir o seu fundamento.

O "Somos" se tornou famoso após contar com matéria na grande imprensa, ${ }^{22}$ no Lampião, ${ }^{23}$ o que influenciou na presença de trinta homossexuais, sendo dez mulheres, em reunião de março de 1979. Durante esse ano, a atividade do grupo que reunia o maior número de integrantes eram as reuniões de identificação, "relatos autobiográficos em que todos os participantes tinham a oportunidade de revelar sua concepção a respeito da sexualidade em geral e a homossexualidade em particular". ${ }^{4}$

\footnotetext{
${ }^{19}$ MELO, op. cit.

${ }^{20}$ Sinônimo ou as iniciais do nome de um dos membros entrevistado por Marcus Ribeiro de Melo. Idem, ibidem.

${ }^{21}$ Ibidem, p. 7.

${ }^{22}$ Alguns exemplos: PEREIRA, Coelho. "Eros, Somos, Libertos". Folha de São Paulo. Folhetim. São Paulo: 16 mai. 1980, p. 6; "Grupo Somos comemora 3 anos de existência”. Folha de São Paulo Ilustrada. São Paulo: 18 mai. 1981, p. 20; "Por uma sexualidade lúdica”. Folha de São Paulo Ilustrada. São Paulo: 19 fev. 1979, p. 24. CARDOSO, Irede. "Grupos homossexuais lutam contra a discriminação". Folha de São Paulo. Primeiro Caderno. São Paulo: 24 nov. 1981, p. 12.

${ }^{23}$ DANTAS, Eduardo. "Negros, mulheres, homossexuais e índios nos debates da USP: felicidade também deve ser ampla e irrestrita". Lampião da Esquina, Rio de Janeiro, n. 10, p. 9, mar. 1979.

${ }^{24}$ MacRAE, 1990, op. cit., p. 129.
} 
Tais encontros eram permeados de emoções, reconhecimento do preconceito social e até tentativas de orgulho da homossexualidade. Colaboravase, assim, na construção de uma identidade homossexual. Nesses encontros, inclusive, metas eram estabelecidas por meio de consenso entre participantes, freando desavenças e tentando criar uma comunidade de iguais. 0 aparecimento do "Somos" no labirinto político da década de 1970 implica uma constante alteração na visibilidade e atuação das homossexualidades no espaço público.

Paralelamente, o Somos e outros grupos que surgiram posteriormente começavam a se mobilizar. Um memorável exemplo foi o I Encontro Brasileiro de Homossexuais, que ocorreu junto ao I Encontro de Grupos Homossexuais Organizados. A ideia do evento foi do Lampião da Esquina. Delegações de vários estados foram convocadas. ${ }^{25}$

O encontro em si foi organizado por uma coalizão entre o "Somos", o EROS e LIBERTOS, estes últimos recém-criados. A sessão de abertura do I Encontro Brasileiro de Homossexuais ocorreu no Teatro do Centro Acadêmico da Faculdade de Medicina da USP e contou com o grupo Somos (SP), Ação Lésbico-Feminista (SP), Eros (SP), Libertos (Grarulhos), AUÊ (Rio de Janeiro), Somos (RJ), Somos (Sorocaba) e Beijo Livre (Brasília). Cerca de duzentas pessoas reuniram-se no auditório.

As metas eram muitas e representantes dos grupos almejavam colocar seus pontos de vista sobre diversas questões. Já na abertura apresentaram uma moção de apoio aos metalúrgicos em greve. ${ }^{26}$ Durante o evento, o debate A questão lésbica. 0 machismo entre homossexuais e papeis sexuais contou com o maior público, cerca de setenta pessoas, e não fechou um consenso para as suas questões. Evidenciou-se naquele dia, segundo Francisco Bittencourt, ${ }^{27}$ que o grupo mais articulado, coerente e com melhor articulação oratória era a Ação Lésbico-Feminista (GALF), inicialmente uma das divisões do Somos/ $\mathrm{SP}$, do qual veio a se separar.

O encontro mereceu ter tomado parte significativa da edição de número vinte e quatro do Lampião da Esquina. Tratava-se não só da constatação de grupos de homossexuais disputando um lugar num país carente de regime democrático. Mais que isso, eles reuniram-se e articularam-se a fim de discutir posições, conjunturas, propor projetos, trocar experiências. A escritora Leila

\footnotetext{
25 “Povo guei se reúne em São Paulo”. Lampião da Esquina, Rio de Janeiro, n. 23, p. 14, abril 1980.

${ }^{26}$ BITTENCOURT, Francisco. Homossexuais, a nova força. Lampião da Esquina, Rio de Janeiro, n. 24, p. 4, mai. 1980.

${ }^{27}$ Idem, Ibidem.
} 
Mícolis narrou: "Indescritível, fico arrepiada até agora só de relembrar aqueles momentos, Ruth Escobar repletíssimo[...]" Dentre as pautas, houve "Todos os tipos de denúncia - dos negros, das feministas, das Convergências - foram postos a nu, com incríveis depoimentos, inclusive de travestis". ${ }^{28}$

O "Somos", que, desde a sua fundação, investia em aparições públicas, ${ }^{29}$ ganhou visibilidade suficiente que lhe permitiu, provavelmente no começo de $1981,^{30}$ conquistar uma sede, localizada na rua da Abolição, no 244, no bairro Bela Vista, em São Paulo. Nela organizaram uma série de atividades, a exemplo do Clube de Cinema "Somos", debatendo filmes que tocavam na questão das sexualidades e, especificamente, das homossexualidades. Com a aquisição, houve espaço para montar um arquivo que reunisse atas de reunião, cartazes de eventos públicos, correspondências, exemplares de jornais e revistas.

Desde o começo de 1981 se tornou famoso o "Plantão" do "Somos", uma reunião aberta ao público. Naquela época ocorria aos domingos, por volta das 15h. Compareciam pessoas interessadas em fazer queixas de preconceito no ambiente de trabalho ou na família, denunciar discriminações e violências, consultar a biblioteca do grupo, compartilhar angústias e alegrias, fazer amizades e buscar informações de como contribuir com o grupo. ${ }^{31}$

A matéria Os homossexuais e seu espaço, da seção De cabo à rabo da revista Rose, publicação homoerótica fundada em 1979 pela editora curitibana Grafipar, tocou na importância da sede do "Somos" como uma alternativa ao gueto homossexual. 0 texto se direcionava aos que vivem no gueto, "pessoas que têm relações homossexuais e não a manifestam publicamente, seja no trabalho, na família, ou em locais de lazer, pela extrema repressão social". o Movimento Homossexual Brasileiro criticava o gueto à medida que buscava libertar da clandestinidade os que viviam uma autorrepressão em virtude de não aceitar a homossexualidade.

Sabe-se que, no caso do "Somos", os plantões pretendiam ensinar os indivíduos a lidar positivamente com a homossexualidade, vestir esse conceito e expô-lo. Para a militância, a existência homossexual estava ligada à sua

\footnotetext{
${ }^{28}$ MíCCOLIS, Leila. "Mulheres compram as brigas". Lampião da Esquina, Rio de Janeiro, n. 24, p.6, mai. 1980. 29 "O grupo "Somos" já tem história”. Rose, Curitiba, Grafipar, n. 54, p. 4.

${ }^{30} \mathrm{Na}$ fonte à qual tive acesso não se menciona quando exatamente a Somos adquire a sede. Mas, como a documentação data daquele ano, possivelmente noticiar a sede significava destacar um evento recente. Há também uma carta escrita por Luiz Mott em 23 de fevereiro de 1981 e enviada ao Somos parabenizando pela conquista da sede, vista como um marco na história do movimento homossexual brasileiro. Ver: ${ }^{31}$ Idem.
} 
visibilidade pública. Quanto mais homossexuais se assumissem, maiores seriam as chances de mostrar que há um grupo lutando e reivindicando direitos.

O plantão nas atividades do "Somos" teve a função não apenas de fazer os presentes falarem sobre suas experiências, sentimentos, sensações. Antes disso, foi preciso fazê-los ter coragem de, certamente, pela primeira vez, falarem sobre o seu desejo em público e aprenderem junto aos depoimentos de colegas que as homossexualidades deveriam ocupar um lugar diferente do de outrora: o público. Era necessário fazer falar as homossexualidades, num exercício que coloca um desejo em cena e igualmente o sujeito que se diz, singularizando sua subjetividade no momento em que se assume. Os relatos de si nas reuniões do "Somos" vieram a configurar igualmente uma prática pedagógica do que era ser homossexual e de quais caminhos levariam a esse aprendizado.

Néstor Perlongher fez essa mesma observação enfatizando que o ritual de iniciação, isso é, grupo de iniciação ou reconhecimento, tinha por objetivo fazer as pessoas falarem e se conscientizarem da sua homossexualidade. Ainda de acordo com Perlongher, os primeiros grupos homossexuais parecem ter se afastado da associação com a imagem do travesti, de modo que a presença deles, a princípio, foi modesta. ${ }^{32}$

As atividades desenvolvidas trouxeram aos seus membros uma importante constatação. Os homossexuais enfrentavam receio de falar de si, das alegrias, percepções, medos, o que se percebia em grande medida no convite do grupo em fazê-los falar do seu desejo, vendo-o positivamente. Os integrantes notavam que, quando se tratava de falar ou fazer atividade política, de combate ao preconceito, por exemplo, se expunham facilmente se comparado à dificuldade de falar de si mesmos. Para lidar com a questão, o grupo se posicionava: "Entre outras coisas, precisamos aprender a falar. Sobre nós mesmos, sobre nossa sexualidade, sobre nosso direito amplo e irrestrito à felicidade. É isso ấ" ${ }^{33}$ Isso é, ser homossexual era falar de si sob a condição de homossexual assumido, que só existe se expõe a sua identidade.

É curioso notar que o trabalho de MacRae sobre o "Somos" leva em consideração sua trajetória de vida enquanto membro do grupo, conforme ele mesmo coloca. A importância dada a determinados temas dentro da organização tem a ver tanto com a sua subjetividade de antropólogo como integrante. Assim, na sua leitura sobre a primeira fase do movimento homossexual, narra

\footnotetext{
${ }^{32}$ PERLONGER, Néstor. 0 negócio do michê: a prostituição viril em São Paulo. São Paulo: Fundação Perseu Abramo, 2008.

33 “Grupo Somos: uma experiência”. Lampião da Esquina, Rio de Janeiro, n. 12, p. 3, mai. 1979.
} 
três possibilidades do assumir-se: “a) perante si mesmo; b) perante o público anônimo; c) perante a família e colegas de trabalho". ${ }^{34}$

No primeiro caso, assumia-se para si e para o grupo. Nesse exercício, aprendiam que o sentimento de culpa e a percepção de si como estranhos e anormais lhes havia sido imposta pela sociedade. Descontruindo essa visão, os veteranos no grupo e na vida gay indicavam festas e locais de sociabilidade.

Perante o público anônimo, envolvia os cumprimentos, que se davam com beijos na boca. O hábito e a ousadia levaram-nos a continuar com o costume em público. Embora temessem represálias, a publicização desses gestos possui uma conotação política de contestação ao status quo. Outra maneira de se assumir em público ocorria quando convidados a participarem de eventos acadêmicos ou a concederem entrevistas.

Finalmente, cumpridas essas etapas, restavam a família e o ambiente de trabalho. Nesse ponto, MacRae diz que o grupo não costumava intervir, pelo menos não explicitamente, uma vez que era comum falar "se assumir não implica em suicídio". ${ }^{35}$

Os grupos de identificação passaram por algumas mudanças. Pedro de Souza, um de seus militantes, disse-me em entrevista que, quando entrou no grupo, no final de 1981, as estratégias de identificação ficaram mais frequentes através de cartas. "O Somos recebia cartas de pessoas contando suas histórias, suas dificuldades para se assumir como gay", ${ }^{36}$ lembra.

Ao longo da história que venho contando aqui, reitero que o se assumir foi uma das principais ferramentas de elaboração do movimento homossexual no Brasil. Essa atitude, na passagem das décadas de 1970-80, estava para o reconhecimento de uma identidade existente apenas quando pessoas se mostrassem e se afirmassem homossexuais.

Em entrevista ao jornal Versus, os membros do grupo foram questionados sobre como ocorria o processo de identificação homossexual dentro do "Somos".

Estamos comprometidos com todos os homossexuais: os que se suicidam; os que ligam para o C.V.V. (Centro de Valorização da Vida) em desespero; os que se entregam ao álcool ou às drogas; quando são internados em manicômios; quando são levados a torturas em prisões; quando são rejeitados em escolas, nas famílias, nas religiões e na sociedade que determinam padrões à sexualidade; quando são vítimas de roubos e chantagens; quando são usados para o roubo

\footnotetext{
${ }^{34}$ MacRAE, 1990, p. 136.

${ }^{35}$ Idem, Ibidem, p. 138.

${ }^{36}$ Pedro de Souza em entrevista ao autor em 19 ago. 2016.
} 
na TV, no cinema, teatro, no rádio, nos jornais, livros e revistas etc.; quando são apontados nas ruas; quando se faz piadas; quando a Imprensa marrom nos vincula à droga, crime ou "anormalidade". E aí pinta a solidariedade e não mais aquela sensação de animal raro. [...]

É por isso que os subgrupos de identificação têm um papel básico dentro do SOMOS. Existem no momento oito deles, cada um tendo entre oito a doze integrantes. Suas reuniões geralmente são aos sábados e aos domingos e duram de três a quatro horas em média. ${ }^{37}$

O trecho dá uma dimensão ampla dos problemas enfrentados pelos homossexuais brasileiros. Diante do leque de dificuldades, seria difícil se dizer homossexual porque muitas vezes viviam essa experiência sob a ideia da dúvida ou da negação, que não cabia na tentativa de construção do movimento homossexual, carente de uma expressiva quantidade de pessoas vistas como pertencentes a uma identidade homossexual.

Os grupos de identificação e a oportunidade de falar de si intensificam a discursividade do assumir. Mesmo em se tratando de um não dito, a publicização existe aí através dos subgrupos, quando a militância relata o número de integrantes, dia e horário de funcionamento e explicando a prática do ponto de vista da solidariedade. A menção a uma série de dificuldades pelas quais passavam as vidas homossexuais, seguida da menção aos subgrupos, fazia do "Somos" um meio para a existência de si.

A primeira frase do trecho acima sinaliza para uma tentativa de acolhimento. Mas, por ser um resposta a respeito de um tema caro ao grupo, se relaciona a uma ordem, a um dos principais objetivos da organização: a publicização da homossexualidade. O que realmente importa na explicação do processo de identificação é a palavra de ordem do se assumir, o testemunho de como os homossexuais são acolhidos; é a asserção de que não estão sozinhos: "E aí pinta a solidariedade e não mais aquela sensação de animal raro".

Nessas reuniões, o medo de falar era contornado nos relatos dos demais, levando a um sentimento de companheirismo e de certo alívio porque alguns presentes na reunião, além de vencerem o medo de se aceitarem e se assumir, adquiriram coragem para exercer cargos no "Somos".

O dizer-se e os desabafos praticados no grupo só se davam pela compreensão de si como sujeito homossexual. A identificação impulsionada pelo "Somos" é parte de uma nova configuração acionada na modernidade, isso é, a classificação das pessoas em uma identidade "que expressa plenamente a

37 “Saímos ao Somos”. Versus, p. 32, abr. 1979. 
real verdade do corpo" ${ }^{38}$ Jeffrey Weeks assinala a sensação de pertencimento em frases "eu sou gay" ou "eu sou lésbica". Mas, justamente por serem identidades, são possibilidades, não uma essência da personalidade; antes, uma posição ocupada, ou melhor, a encenação de ocupar tal posição. Um dos usos dessa concepção de identidade sexual foi acionado para marcar separações e individualidades. "Os processos de categorização e auto categorização (isto é, o processo de formação da identidade) podem controlar, restringir e inibir, mas simultaneamente oferecem conforto, segurança e confiança". ${ }^{39}$

Ainda de acordo com o historiador, uma das possibilidades de formação de uma identidade pessoal estigmatizada pode ocorrer, mesmo com ressalvas, a essa divisão: sensibilização - o indivíduo se percebe na sua diferença em relação à norma; significação - elaboração de sentidos sobre a sua diferença; subculturalização - reconhecer-se pertencendo a uma identidade; estabilização - aceitação de uma identidade e participação numa comunidade que partilhe dos mesmos objetivos e estilos de vida.

Em cinco anos, o "Somos" cumpriu um papel decisivo na primeira onda do movimento homossexual brasileiro, pois colaborou para a reivindicação de direitos para os homossexuais em atos públicos, congressos e passeatas.

De acordo com o relato de Pedro de Souza, um dos membros da organização, por volta de 1982 já era notável que o "Somos" ia perdendo adeptos e interessados. A cada reunião, o número de participantes era menor. Na sua opinião, "A rua era mais interessante do que o espaço do Somos" devido à profusão de espaços de sociabilidade. Sobre o término da organização, ele rememora:

O Somos começou a existir justamente para afirmação, ou seja, para lutar para a exposição gay, para que as pessoas pudessem... E houve muita luta, muito enfrentamento com a polícia e tudo o mais. Então ao longo do tempo o Somos começou a perder o sentido porque a causa para a qual ele veio já tinha sido praticamente... digamos... vencida. É como se não tivesse mais razão de ser... Não havia mais adesão! Até para você ter uma ideia, grupo de identificação não tinha mais sentido porque as pessoas não precisavam mais disso. As cartas começaram a rarear. 0 grupo não recebia mais tantas cartas. ${ }^{40}$

Embora diversas narrativas possam ser acionadas para explicar o término do grupo, o depoimento de Pedro permite algumas observações. Primeiro,

\footnotetext{
${ }^{38}$ WEEKS, Jeffrey. "O corpo e a sexualidade”. In.: LOURO, Guacira Lopes (Org.). O corpo educado: pedagogias da sexualidade. Belo Horizonte: Autêntica, 2015. p. 35-81.

${ }^{39}$ Idem, Ibidem, p. 70.

${ }^{40}$ Pedro de Souza em entrevista ao autor em 19 ago. 2016.
} 
a questão que teria motivado o nascimento do grupo, ou seja, a afirmação, o se assumir, tomar o espaço público afirmando a identidade homossexual. As atividades da organização, em grande medida, buscavam a inserção de uma figura até então indigna de aparecer positivamente nos espaços públicos. 0 esforço do "Somos" teria sido, dentre outras razões, criar esse lugar.

Essa colocação do entrevistado é posta logo quando pergunto sobre as possíveis causas do fim da organização. A resposta parecia estar suficientemente clara nas suas memórias. Parece que a função do "Somos" era modificar percepções das homossexualidades que, conectadas ao se assumir, visavam lutar por direitos. Num país com tamanha heterogeneidade como o Brasil, essa "conquista" se deu em poucas cidades e, ainda assim, jamais em sua totalidade.

A campanha da visibilidade das homossexualidades no "GGB" teve em Luiz Mott seu principal mentor. $O$ antropólogo, em livros, artigos e entrevistas desde então tem advogado que os/as homossexuais devem assumir, não deixando de "tirar do armário" personagens famosos da história do Brasil, informando que eram homossexuais. Assim diz ele sobre Zumbi dos Palmares e Lampião. Para além do anacronismo, a questão parece ser tão central no lado intelectual e militante de Mott, que em seu livro Crônicas de um gay assumido, além da dupla reivindicação do título, pode-se ler já no primeiro parágrafo:

Ainda hoje, raros são os homossexuais no Brasil que têm a ousadia de escrever na primeira pessoa. A grande maioria dos gays e lésbicas - mais de $95 \%$ permanecem ainda dentro da gaveta, vivendo clandestinamente o que para a maioria dos seres humanos é motivo de orgulho e reconhecimento social: o amor. [...]

Afinal, já é tempo que igualmente entre nós mais e mais gays, lésbicas e travestis assumidos ocupem as estantes das livraras e bibliotecas e, por que não?, vistam o fardão das academias de letras, pois se tantas obras de homossexuais enrustidos foram e continuam a ser aplaudidas, é chegado o tempo de os gays assumidos receberem o merecido reconhecimento. ${ }^{41}$

No livro, Mott narra o seu assumir-se: "resolvi ser senhor do meu presente e futuro"; "tive coragem suficiente para dar este passo vital que mudou completamente não só o rumo, mas a própria estrutura da minha existência: tornei-me um gay assumido"; "desde então, jamais desperdiço uma oportunidade para contar a todos a felicidade que encontrei ao assumir minha essência existencial". ${ }^{42}$

\footnotetext{
${ }^{41}$ MOTT, Luiz. Crônicas de um gay assumido. Rio de Janeiro: Record, 2003. p. 9-14.

${ }^{42}$ Idem, Ibidem, p. 141.
} 
No mesmo texto, atribui a si mesmo um papel considerável na história das homossexualidades no Brasil. Diz ter orgulho em ser o decano do movimento homossexual brasileiro e ter se tornado "o homossexual mais visível no país neste final de século, o gay brasileiro mais conhecido dentro e fora de nossas fronteiras".

O historiador Ailton Carneiro destaca que, desde a fundação, o "GGB" esteve preocupado exclusivamente com a questão da homossexualidade, diferindo do "Somos", cujas discussões envolviam igualmente a questão da luta de classes. Ailton sustenta que enquanto o "'Somos' trazia a necessidade de uma afirmação identitária homossexual no próprio nome, o GGB já nasce com essa identidade definida e consolidada compondo uma de suas siglas". ${ }^{43}$ Ainda que contasse com uma identidade definida, possivelmente ela se modificava com caminhos a seguir e metas a traçar, mesmo porque um grupo é também movido por disputas de poder e dissensões. Além do boletim, o "GGB" produziu um pequeno livro de poemas, fruto de concursos realizados pela organização. Possivelmente, o primeiro desses livros data de 1982 e, dentre os poemas selecionados, dois deles tocam na questão do se assumir:

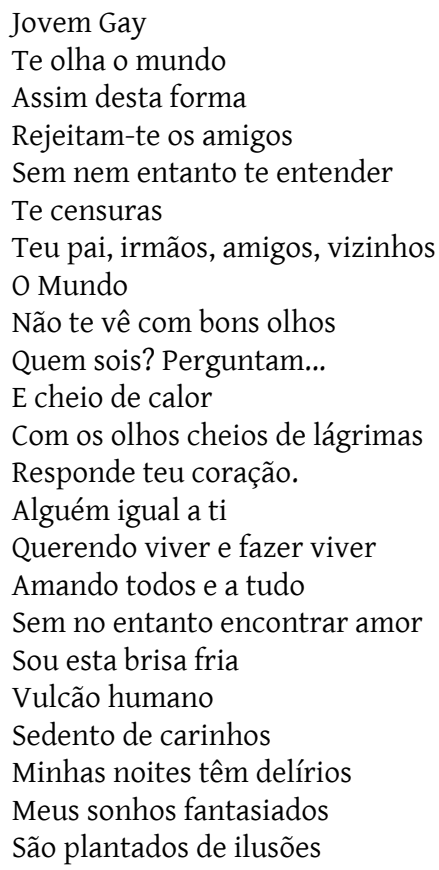

${ }^{43}$ CARNEIRO, Ailton. "Salvador dos homossexuais: militância homossexual e homossociabilidade na Bahia nos anos 1980". Temporalidades, Belo Horizonte, UFMG, v. 7, n. 3, set./dez. 2015, p. 17. 


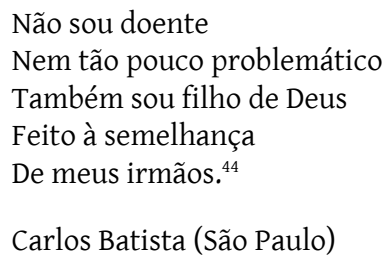

O eu lírico põe em evidência a sua visão de mundo, focada na ausência, no silêncio dos seus sentimentos, na não aceitação social e familiar. Partindo de tudo isso, o poema inverte a lógica comum do tempo que o viu nascer. Constrói uma defesa para as homossexualidades, faz uma ode à visibilidade das homossexualidades que passaria, necessariamente, pelo desejo de ser aceito e visto como igual - "também sou filho"; maneira comum na primeira onda do movimento homossexual brasileiro quando se buscava o reconhecimento pela igualdade.

A escrita de Carlos Batista é uma reivindicação de muitas outras vozes que, Brasil afora, viviam situações semelhantes. Privadas no e do mundo, restava-lhes a solidão, a dor, sentimentos que ecoam no poema acima. Quando o eu lírico se pronuncia, ele intervém nessas sensibilidades, compartilha, divide e, ao mesmo tempo, verbaliza, para muitos, questões que, embora particulares, parecem tratar de uma coletividade.

Uma série de palavras e expressões direciona para a solidão do eu lírico: sonhos fantasiados; rejeitam; te censuram; querendo viver. A última expressão, cujo trecho é anteriormente mencionado, fecha o poema e expõe uma luta discursiva para se inserir numa coletividade, talvez a maior que pudesse se conceber, aquela que agrega e une milhares de pessoas e, não obstante, prega o amor acima de tudo: "também sou filho de Deus". O tom religioso e cristão que encerra o texto não deflagra um tom moralista ao poema e tem uma função clara: a aceitação, porque mesmo com uma série de argumentos adversos, inclusive do ponto de vista religioso, os preceitos religiosos pregam a união universal, todos filhos de Deus, e, por consequência, irmãos: "feito à semelhança/ de meus irmãos". Ou seja, o eu lírico vale-se da premissa de que todo o ser possui uma crença, desenvolvida por meio da adesão aos ritos de uma religião, a qual prega a igualdade entre os seres - embora dentro da Igreja, por muito tempo, inclusive hoje, nasçam muitos dos preconceitos contra os homossexuais - para, implicitamente, implorar aceitação. Aceitação esta incondicional, uma vez que o eu lírico mostra convicção de sua identidade - "Sou

${ }^{44}$ BATISTA, Carlos. “Jovem Gay”. In: . Poemas Gays. Grupo Gay da Bahia: Salvador, 1982. 
esta brisa fria/Vulcão humano/ Sedento de carinhos/ Não sou doente/ Nem tão pouco problemático". Ao mesmo tempo, ele pede adesão ao que seria razão de preconceito, sua identidade de gênero, mencionando outras formas de preconceitos que, igualmente, excluem: no caso, os doentes e problemáticos.

De alguma forma, o "GGB" sabia desse novelo de emoções e, no mesmo livreto, apresentou um poema que poderia funcionar como ajuda em casos semelhantes ao narrado no poema de Carlos Batista:

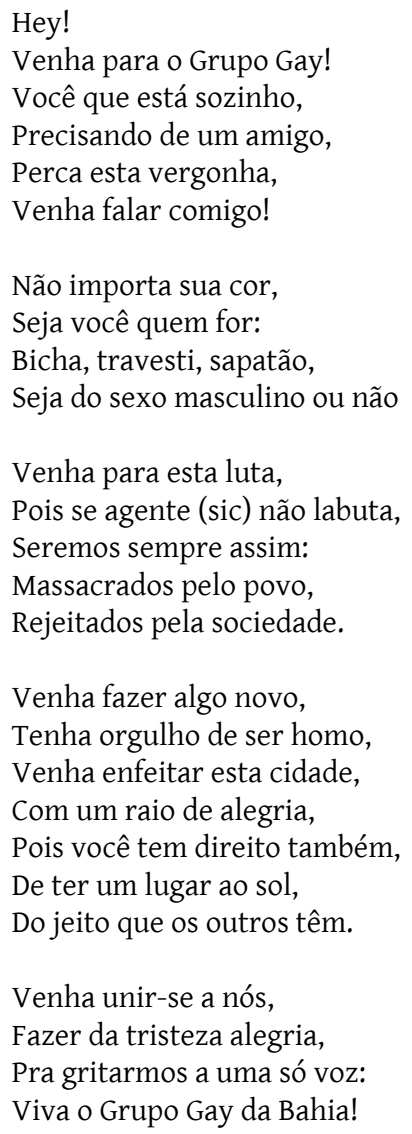

Estamos diante de um convite. Não é um convite de um evento frequente, contínuo, corriqueiro; pelo contrário, é um acontecimento e se fundamenta pelo seu ineditismo. Essas organizações existem porque resistem à maneira como eram vistas, tratadas e percebidas as homossexualidades. Seus participantes entendiam que pessoas que desejavam outras do mesmo sexo viviam certa solidão devido ao estigma construído sobre o seu desejo - "Pois você 
tem direito também, / De ter um lugar ao sol". No poema, todavia, o tom é celebrativo, pois, ao contrário do eu lírico do poema "Jovem Gay" (título que remete a 'um'), aqui, o eu lírico se pronuncia de um lugar onde não está só.

O poema traz um convite para um novo mundo, que era a militância, tal qual se anuncia em meio aos versos e estrofes. A função apelativa é oportuna nestes casos. Precisa-se de novos integrantes e colaboradores, precisa-se de pessoas que atendam aos propósitos empreendidos pelo "GGB", qual seja: "Venha para esta luta, Venha falar comigo!, Venha unir-se a nós, Venha para o Grupo Gay!”. Embora a função da linguagem predominante no poema seja a emotiva, típica de poemas e expressões do eu, não deve ter sido gratuito que, das cinco estrofes, quatro comecem com o uso apelativo da linguagem. Para atender a esse convite, era preciso uma senha, também dada ao leitor: “Tenha orgulho de ser homo".

Em 1982, ano de eleições para governadores, senadores e deputados, o número 68 da Rose trouxe na seção Cabo a Rabo um trecho de artigo escrito por Luiz Mott, "Homossexual confesso", e enviado para a revista cujo título era "Os homossexuais e a política". ${ }^{45} \mathrm{Nele}$, ativistas destacam alguns números. Sabia-se que $10 \%$ da população dos países ocidentais era de homossexuais. No Brasil, isso significava 11 milhões de pessoas. Cita, ainda, uma pesquisa feita com 80 travestis de Salvador, na qual mais da metade tinha o curso ginasial completo e uma era analfabeta. A intenção do texto tem a ver com as eleições de 1982 e o objetivo de mostrar aos homossexuais que constituíam uma força política não ignorável como eleitores. Mas, para se mostrar como força, os homossexuais precisariam expor publicamente o seu desejo.

À época, apenas o deputado João Breda, do PT de São Paulo, sinalizou para a defesa dos homossexuais. Outro membro do seu partido, Luiz Ignácio Lula da Silva, declarou, em plenário no Senado Nacional: "Não aceitaremos que, em nosso partido, o homossexualismo seja tratado como doença e muito menos como caso de polícia. Defendemos o respeito que merecem essas pessoas". ${ }^{46} \mathrm{O}$ Partido dos Trabalhadores saiu na frente no apoio aos homossexuais, bem como no começo dos anos 1980 se mostrava sensível à luta dos índios, negros e mulheres.

Tentando incentivar uma politização por parte dos homossexuais, Mott escreve que, nos Estados Unidos, há deputados e senadores

\footnotetext{
45 “Os políticos e os gueis". Rose, Curitiba, Grafipar, n. 68, p. 4.

${ }_{46}$ "PT se pronuncia oficialmente em favor do homossexualismo". Rose, Curitiba, Grafipar, n. 66, p. 5.
} 
“assumidamente gueis" e, na Noruega, a deputada lésbica Wnche Lowzou ${ }^{47}$ conseguiu a inclusão de artigo no Código Penal de seu país que pune com multa ou até dois anos de prisão casos de homofobia. A ideia era difundir essas conquistas criando um horizonte de expectativas no Brasil, que já contava com grupos e precisava de pessoas aderindo ao movimento, o que exigia a performance de se assumir.

No dia 28 de junho de 1981, Dia Internacional do Orgulho Gay, o "GGB" organizou o show "Cheguei, sou Gay" para mais de 300 participantes, no Teatro Gregório de Matos. No boletim, constava a referência à data, um dia de luta contra a opressão e "nossa libertação", presumindo, portanto, que havia algo preso dentro do indivíduo desejando se libertar; uma visão essencialista da homossexualidade.

O discurso acionava maneiras diversas de tocar no assumir-se. Os militantes do "GGB" partilharam com o público a expressão "Saia da gaveta" - importante ressaltar que não era "saia do armário" -, dizendo se tratar da palavra de ordem do movimento gay "universal”. Executar esse ato era revelar para o mundo que se era gay e, outro desafio, que gostava de ser. 0 grupo presumia a dificuldade de o público seguir a dica e aconselhava a ir saindo aos poucos. Chegaria o dia em que se mostrariam por inteiro. "Somos muitos. Estamos em toda parte e estamos dispostos a lutar porque necessitamos e vamos conseguir um lugar ao sol. Cheguei, sou Gay!". ${ }^{48}$

Este discurso foi apresentado no boletim de número 1, o primeiro produzido pelo grupo. A função da primeira edição de um boletim geralmente é divulgar da maneira clara e convincente os seus principais propósitos, o que explica a presença desse texto. Dado importante foi mencionar a presença de mais de 300 pessoas na festa no Gregório de Matos. A ordem das centenas destaca não só um número que não deveria ser ignorado, mas, também, associando-se com o conteúdo do discurso, vem dizer que aquele movimento já contava com uma quantidade suficiente de adeptos. O teor do assumir-se nos grupos tem um vetor político. Conforme estou demonstrando, não parece uma característica de foro íntimo. Na forma expressa pela militância, a publicização era algo público e já naturalizado para ir a público.

Modificar letras de famosas composições da música brasileira tencionando-a para a temática do assumir-se foi outra estratégia lançada pelo GGB. Um exemplo:

\footnotetext{
${ }^{47}$ Até o momento não consegui nenhuma fonte que corroborasse essa afirmação.

${ }_{48}$ "28 de junho: Dia Internacional do Orgulho Gay”. Boletim Grupo Gay da Bahia, Salvador, n. 1, p. 18, ago. 1981.
} 


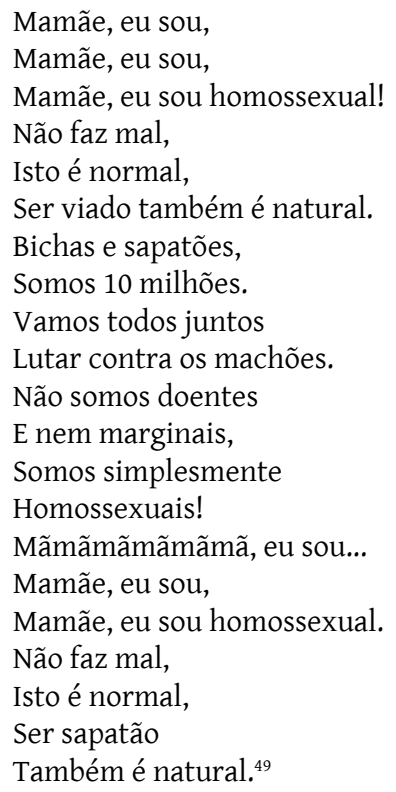

Estamos diante de uma versão modificada de Mamãe eu quero, escrita em 1936 por Jararaca e Vicente Paiva. A música fez sucesso sobretudo nos tempos carnavalescos e é lembrada com nostalgia nos dias de hoje. Ao seu tempo, imortalizou-se na voz de Carmem Miranda e alcançou sucesso nos Estados Unidos, ganhando uma versão inglesa. Uma crítica interna dessa música exigiria ouvi-la várias vezes, se possível em interpretações distintas a fim de inventariar eventuais modificações, debruçar-se na sua partitura. ${ }^{50}$ Porém, não tenho acesso a tal material. Aliás, dadas as difíceis condições estruturais do "GGB" no começo da militância, é provável que não tenha sido gravada uma versão modificada, apenas copiada e distribuída textualmente, certamente intuindo que seguisse o modelo da canção na qual se inspirou. Desse modo, leio não propriamente a música, o que exigiria a sua melodia, sons, notas, mas, sim, a letra, o texto, o que, enfim, foi possível alcançar até aqui.

A popularidade da música contribuiu para ser escolhida pelo Grupo Gay da Bahia. Ela funciona como um hino de homossexualidade com objetivo duplo. Primeiro, é mecanismo de publicização seguido de imediato de

\footnotetext{
49 “Gaias paródias gueis". Rose, Curitiba, Grafipar, n. 77, p. 7.

${ }^{50}$ Recomendações expressas em RICON, Leandro Couto Carreira. "Por uma História Social da Música: uma metodologia aplicada à produção operística”. História e Cultura, v. 2, p. 81-98, 2013.
} 
uma explicação que amenizasse o espantou (ou não!) diante de tal afirmação: "Mamãe, eu sou homossexual!/ Não faz mal,/ Isto é normal". O que se elegeu modificar da letra original tenta criar condições para a aceitação do desejo. Os termos "é natural", "não somos doentes/ E nem marginais" e "Ser sapatão/Também é natural" aludem para um dos primeiros objetivos do "GGB": retirar a homossexualidade do quadro de doenças do Código de Saúde do Instituto Nacional de Assistência Médica e Previdência Social (INAMPS), que, no seu parágrafo 302.0, a considerava "desvio e transtorno sexual". A partir do momento em que o folheto é assinado pelo Grupo Gay da Bahia, tem-se um referente que se mostra, se deixa ver, esclarece a razão de estar ali na modificação que faz da letra original.

O segundo objetivo explica o porquê daquela letra e a afirma como um dos possíveis hinos da homossexualidade brasileira naquele momento. Ela tinha sido criada em virtude das comemorações do "Dia Internacional do Orgulho Guei" e foi distribuída no dia 28 de junho. Panfletar essa letra nessa data comemorativa indicava que ela merecia ser conhecida, comemorada e lembrada. Outro fator era acionado na construção dessa data, o fato de que não se estaria sozinho por ser homossexual: "Somos 10 milhões". Faltava ao movimento fazer ver esse número, mas, enquanto isso não ocorria, falavam pelos homossexuais, retiravam-lhe a voz, ou melhor, lhes atribuíam uma voz, uma identidade, ignorando, quem sabe intencionalmente, se os homossexuais assim se identificavam ou, como é mais nítido na documentação da revista Rose, se sabiam o que era ser homossexual e assumir essa identidade.

A letra anterior insere palavras de ordem - onde o imperativo tem uma "obrigação social" - que delimitam um ato de linguagem, uma intervenção na realidade. Uma afirmação, um pronome, a exemplo de Mamãe, eu sou, são palavras de ordem. É o assumir-se implícito aí que pode habitar nos leitores, modificando-lhes a relação consigo mesmos. Como refletiram Deleuze e Guattari: "Não existe significância independente das significações dominantes nem subjetivação independente de uma ordem estabelecida de sujeição. Ambas dependem da natureza e da transmissão de palavras de ordem em um campo social dado". ${ }^{51}$

Tornava-se relativamente frequente nas publicações do "GGB" o termo gay, mesmo que homossexual predominasse. Seja como for, fazer da

${ }^{51}$ DELEUZE, Gilles; GUATTARI, Félix, op. cit., p. 18. 
sexualidade uma qualidade do eu significava gestá-la, interrogá-la e desenvolvê-la ${ }^{52}$ e, principalmente, fazer vê-la.

O "GGB", no boletim de número um, expressava o foco na publicização das homossexualidades. Lá constava: “'Saia da gaveta!' Quer dizer: saia à luz, chega de nos ocultar [...]. Vamos sair da gaveta e revelar para todo mundo que somos gays, que gostamos de ser". ${ }^{53}$ Aos que tivessem medo de seguir a dica, aconselhava-os a dizer aos poucos, evitando represálias em casa, na escola, no trabalho. No carnaval de 1982, os "gegebetes" (maneira-como os integrantes do GGB se autorreferiam) distribuíram panfletos, sugerindo: "Se assuma gay o ano inteiro. Só no carnaval é muito pouco. É legal ser homossexual". ${ }^{54}$

Embora distante geograficamente do "Somos", o "GGB" partilhava do objetivo de tocar no assunto da visibilidade das homossexualidades. Uma intensa política foi travada ao longo dos anos 1970 para estimular a criação e exibição de identidades de diversos grupos, inclusive os estigmatizados socialmente. Acreditava-se que a criação dessas identidades atendia ao propósito de se fazer existir numa sociedade que costumeiramente tolheu direitos de alguns grupos civis. No caso das homossexualidades, esse empreendimento foi levado a cabo também por publicações homossexuais, a exemplo do Lampião da Esquina e da revista Rose.

A parceria entre "GGB" e o "Dialogay" parece ter sido fecunda o bastante para ter levado Luiz Mott a Aracaju. Lá proferiu palestras na Universidade Federal de Sergipe e noticiou atividades desenvolvidas pelo grupo baiano ou opiniões sobre a causa gay. O boletim da organização sergipana transcrevia matérias publicadas pelo "GGB":

\section{Por que temos orgulho de ser gay?}

Foram necessários séculos de resistência, luta e contestação para que chegasse o dia, na década de 60, em que os negros pudessem declarar: "NEGRO É BONITO". Será preciso quantas gerações, para que todas as pessoas reconheçam que as mulheres têm os mesmos que (sic) os machos, que a cor escura do índio ou do negro não implica em inferioridade? Não existe raça superior. Não existe sexo superior e nem sexualidade superior. Sexo é prazer, comunicação, vida. É um direito inalienável de todo ser humano. Homossexual, bissexual, heterossexual, tudo é válido, legitimo (sic), natural, saudável e bonito, questão de preferência individual. Negro é bonito. Bicha é bonito. É bonito ser lésbica. Ser homossexual não é doença, nem pecado, nem crime. É legal ser homossexual. Não temos

\footnotetext{
${ }^{52}$ GIDDENS, Anthony. A transformação da intimidade: sexualidade, amor e erotismo nas sociedades modernas. São Paulo: UNESP, 1993. p. 24.

${ }^{53}$ Op. cit., p. 20.

${ }^{54}$ “A praça Castro Alves é das bichas???????”. Boletim Grupo Gay da Bahia, Salvador, n. 3, p. 45, 1982.
} 
vergonha de amar e fazer amor com pessoas do mesmo sexo. Temos orgulho de ser homossexual (Grupo gay da Bahia). ${ }^{55}$

A presença desse texto demonstra a parceria de ambos os grupos. A preocupação que predominava na associação era a de organização de movimentos homossexuais, elegendo o combate ao preconceito como eixo central, sem deixar de trazer um alerta sobre questões de violência, conforme indica o seu slogan "gay unido é gay alerta e livre".

Uma das estratégias do "Dialogay" era as reuniões que ocorriam nas quartas e sábados, entre às 18-21h, em que cartas e publicações (a exemplo do Boletim do GGB) eram lidas pelo o grupo. Talvez já nessa época o grupo funcionasse na sede do Diretório Central dos Estudantes, da Universidade Federal de Sergipe, por onde permaneceu por cerca de 20 anos.

É oportuno conhecer um pouco o Boletim do grupo:

Dialogay, n. 3

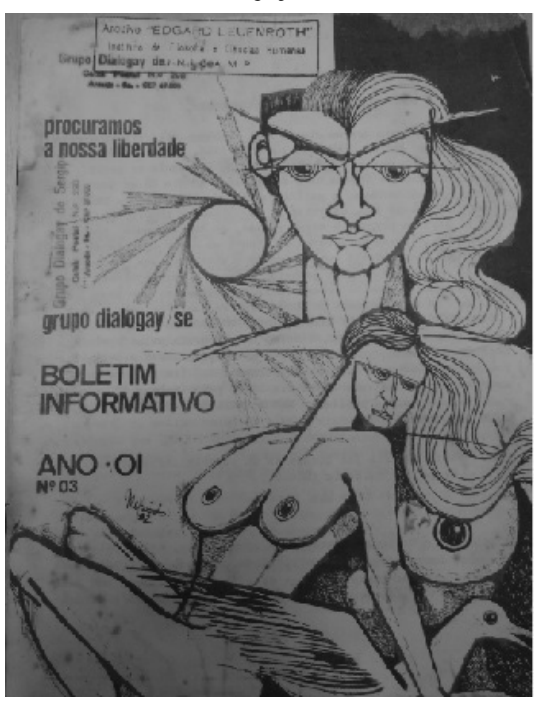

Dialogay, $n .6$

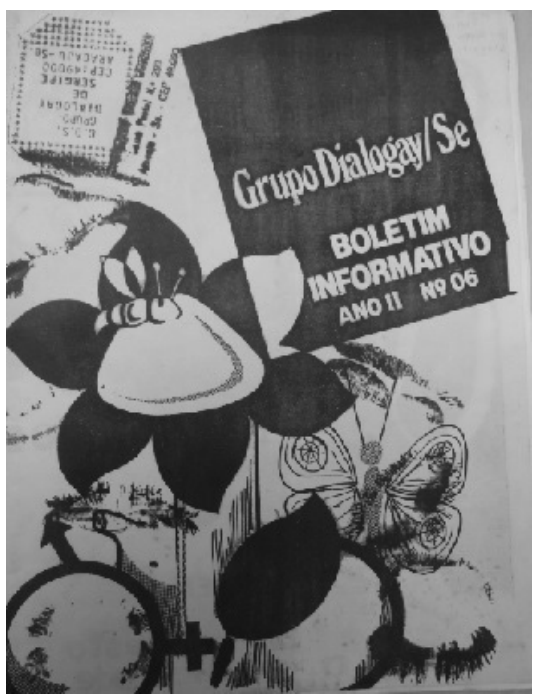

Com aparência modesta, o boletim foi produzido cerca de um ano após as atividades do grupo. Nas edições consultadas, não constam fotos apontando para duas razões: os gastos com impressão ou o anonimato daqueles que preferiam não ter suas imagens divulgadas em um boletim destinado a homossexuais. Por razões de custos, os boletins permanecem preto e branco

55 “Por que temos orgulho de ser gay?". Boletim informativo grupo Dialogay/SE, n. 3, s.d. 
e, dada a aparência, se tratavam de produções caseiras, produzidas em máquinas de datilografar e, certamente, com pouquíssima tiragem. Não havia preço de capa indicando que provavelmente o boletim era distribuído, e com particular exclusividade, aos demais grupos gays do país.

Os grupos homossexuais brasileiros daquele momento investiam na troca de correspondências, boletins, compartilhamento de notícias e demandas em comum. Era frequente que um apresentasse campanhas e atividades realizadas por outros numa estratégia de mostrar que o movimento ocorria em âmbito nacional.

Notável atividade nesse sentido foi organizada pelo grupo AUÊ, do Rio de Janeiro, em 9 de agosto de 1982, quando realizou, na Casa Estudante do Brasil, o curso Introdução à História da Sexualidade, cujo propósito era estudar a sexualidade na longa duração, atentos às concepções e usos do erotismo e da sexualidade na civilização ocidental..$^{56}$

Parte do espaço público se modificava com a presença desses grupos, bem como com as demandas, muitas vezes inéditas, que colocavam na ordem do dia com os temas que noticiavam. Não deve ter passado despercebido aos/as que leram o boletim número 5 a notícia do casamento entre Claudio e Martins. A cerimônia ocorreu em 31 de julho de 1982, no bar Plaiguei, na orla da praia de Atalaia, capital sergipana, e contou com a presença de "casais heterossexuais". ${ }^{7}$

T.D.U., vice presidente do "Dialogay" entre 1981-1983, recordou que uma das principais preocupações do grupo era as estratégias para dar visibilidade às homossexualidades. Segundo Gilvan dos Santos, ${ }^{58}$ o grupo usava o slogan "É legal ser homossexual", uma estratégia na busca por visibilidade, e o mesmo slogan do "Grupo Gay da Bahia".

Os boletins de grupos homossexuais possivelmente não contavam com nenhum patrocínio e, dependendo das localidades, as organizações possuíam pouquíssimos adeptos, concentrando as atividades nas mãos de algumas poucas pessoas.

Outro entrave era que a maioria dos integrantes não contava com experiências militantes que colaborassem na difusão de suas ideias e atividades. Somado ao medo de ser descoberto homossexual por organizar essas reuniões, os membros do movimento homossexual da primeira onda enfrentavam

\footnotetext{
56 “AUÊ \& Somos Informa”. Boletim informativo grupo Dialogay/SE, n. 5, s/d.

57 “Casamento homossexual". Boletim informativo grupo Dialogay/SE, Aracaju, ano 02, n, 5, s.d.

${ }^{58}$ ROSA, Gilvan dos Santos. Terceiro Setor: um estudo no Grupo Dialogay de Sergipe. Monografia (Especialização no Terceiro Setor e Políticas Públicas) - Universidade Tiradentes, Aracaju, 2005.
} 
inúmeros desafios. Esses militantes, vivendo quase simultaneamente a dupla experiência de se perceber homossexual e se constituir enquanto militante, possivelmente tenham exercido amadoramente as funções que lhes cabiam.

Existir não era fácil. Os grupos de militância enfrentavam perseguições moralistas e repressivas que afetam a sua organização e atuação. ${ }^{59} \mathrm{Um}$ dos entraves experimentados pelo assumir-se se dava com a segurança dos membros das organizações, uma vez que se dizer, ou se manifestar, poderia ter efeitos negativos:

Um componente ativista recebeu de seu pai, uma mensagem de solidariedade pela repressão social. E aqui publicamos esta mensagem como exemplo de incentivo a outros pais:

“... Um abraço e muitas felicidades pra você. E muito juízo, nada de dizer o que é, deixe as coisas como estão entre você e seu colega, talvez ele não entenda e passe a ficar uma situação difícil para os dois; porque as pessoas como você têm de manter a sua personalidade de homem (homo, é claro). Decente. Nada de se mostrar, ok?". ${ }^{60}$

Alusiva a presença desse texto no boletim porque vai de encontro à campanha da publicização da primeira onda do movimento homossexual brasileiro. Não deixa de trazer o assumir-se, ainda que o faça pelos riscos de se mostrar com uma performance considerada homossexual. O conselho do pai tem a função de preservar o filho de quaisquer discriminações e indica o nível de homofobia da sociedade da época. $O$ pai permitia ao filho ser homossexual, sob a condição do sigilo, de ocultar o lado "homo". Ao aconselhá-lo a não se mostrar, poderia, ainda, estar se referindo a uma visibilidade pública das homossexualidades crescentes em algumas cidades.

Infere-se que a reivindicação de uma identidade gay, proposta por estes grupos, era, portanto, algo recente e baseado na afirmação do desejo. As atividades e boletins dessas organizações investiam em formas de comportamentos homossexuais, em que o orgulho de ser homossexual e a publicização da identidade foram fatores decisivos.

Naquele momento da história do Brasil, homossexuais foram influenciados por movimentos sociais que emergiam contemporaneamente, especialmente o das mulheres e dos negros. Ciosos de criar uma consciência de luta e construção de um movimento com características próprias, os grupos homossexuais se preocuparam em assumir publicamente as homossexualidades,

\footnotetext{
${ }^{59}$ ZANATA, Elaine Marques. "Documentos e identidade: o movimento homossexual no Brasil na década de 80". Cadernos AEL, n. 5, 1996/1997.

${ }_{60}^{60}$ "Carta de pai pra filho distante". Boletim informativo Grupo Dialogay /SE, ano 1 n, 4, s.d
} 
uma maneira de expor uma identidade, uma máscara de pertencimento que pudesse reunir vários sujeitos no adjetivo homossexual a fim de, dentre outros atributos, conquistarem direitos sociais e combater os preconceitos que lhes atingiam.

De acordo com Michel de Certeau, ${ }^{61}$ um grupo se fabrica como unidade social quando assume o risco de existir e, assim, pode alcançar uma unidade política. A negritude, exemplifica o historiador, existe quando pessoas escolhem existir, mesmo sob perigo. Aplico semelhante raciocínio no movimento homossexual brasileiro. Todas as batalhas travadas, vencidas e perdidas até hoje se deram pela difusão de uma identidade homossexual que os indivíduos deveriam ter a coragem de chamar de sua. O movimento homossexual investiu na elaboração de uma bandeira pública, como se a homossexualidade existisse para ser exposta, como se seus adeptos fossem outdoors ambulantes de seus desejos, como se para estar homossexual fosse preciso publicizar.

Michel Foucault e Judith Butler assinalaram a necessidade da identidade para alcançar demandas sociais. Para a filósofa americana, haveria contextos que exigiriam uma demanda por reconhecimento e, nesses casos, uma - atentemos para o artigo indefinido - das formas seria estabelecendo uma identidade..$^{62} \mathrm{O}$ francês via a importância da identidade homossexual na conquista de direitos humanos e no prazer que ela pode dar às pessoas, mas, ao mesmo tempo, sinalizava que não podia ser uma regra universal. ${ }^{63}$

A história da politização da homossexualidade teve na publicização do desejo um dos seus principais personagens. Assumir-se constituía um projeto político dogmático o suficiente para ignorar se as pessoas que se relacionavam com outras do mesmo sexo sequer conheciam a palavra homossexualidade ou se estavam confortáveis em viver esse rótulo. Indagar o assumir-se é questionar o movimento homossexual, ocasionalmente superestimado e tratado de maneira hegemônica por alguns colegas.

Visitar as fontes de e sobre esse momento decisivo da história das homossexualidades no Brasil é se deparar com investimentos, disputas, acordos visando colocar em público, fazer aparecer um grupo que não podia mais ser ignorado. Num momento em que negros, mulheres e trabalhadores tentavam

\footnotetext{
${ }^{61}$ CERTEAU, Michel de. “Minorias”. In.: CERTEAU, op. cit., p. 145-159.

${ }^{62}$ BUTLER, Judith. "Boa parte da teoria queer foi dirigida contra o policiamento da identidade". Com ciência: Revista Eletrônica de Jornalismo Científico. Dossiê Gênero, Campinas, UNICAMP, 2017. Disponível em: http://www.comciencia.br/entrevista-com-judith-butler/. Acesso em: 15 mar. 2017.

${ }^{63}$ FOUCAULT, Michel. "Michel Foucault, uma entrevista: sexo, poder e a política da identidade". In: Ditos e escritos. Volume IX: Genealogia da ética, subjetividades e sexualidade. Rio de Janeiro: Forense Universitária, 2014. p. 255.
} 
se articular formando organizações para lutar por temas particulares, um grupo de homossexuais, a exemplo dos que integravam o "Somos", "GGB" e "Dialogay", resolveram integrar esse quadro e elegeram como vetor decisivo o se assumir homossexual. Por meio de publicações impressas, reuniões em sede própria ou não, participação em festas populares, troca de correspondência, leitura de obras focadas na homossexualidade, realização de concursos de poesias, indivíduos foram aprendendo a se fazer sujeitos na publicização da homossexualidade. Assumir-se publicamente homossexual era ser interpelado por aquelas instâncias discursivas que prometiam uma notável modificação subjetiva nos seus interlocutores. Em alguns, o se assumir sofreria uma mutação histórica decisiva em função da emergência da Aids. Mas isso é outra história.

Artigo recebido para publicação em 29/10/2016

Artigo aprovado para publicação em 02/06/2017 